Mr Milan Krsmanović, kapetan I klase, dipl. inž.

Vojna akademija, Beograd

\section{PRIMENA PROGRAMSKOG PAKETA MATLAB PRI SIMULACIJI RADA SISTEMA ZA PRENOS SNAGE}

UDC: $62-232.1:[004.42: 510.6$

Rezime:

Rad se odnosi na veoma savremenu problematiku primene programskog paketa MATLAB za simulaciju rada sklopova transmisije motornih vozila. Osnovni cilj je doprinos razvoju procesa projektovanja sklopova transmisije za motorna vozila putem integracije različitih metoda $i$ postupaka, kojima se mogu obuhvatiti faktori koji određuju proces prenosa $i$ transformacije parametara snage (obrtnog momenta i ugaone brzine). Posebna pažnja posvećena je simulaciji rada glavne frikcione spojnice u slučaju polaska vozila iz mesta. U okviru toga detaljno je prikazan način formiranja simulacionog modela frikcione spojnice sa prikazom razvijenog matematičkog modela kao osnove za formiranje simulacionog modela.

Ključne reči: modeliranje, frikciona spojnica, simulacija.

\title{
MATLAB SOFTWARE APLICATION FOR POWER TRANSMISSION SIMULATION
}

Summary:

This paper refers to modern problems in using the MATLAB program package for the simulation of motor vehicle transmission functions. The main goal is to contribute to the development of the process of motor vehicle transmission design by combining different methods and procedures comprising factors which determine the transmission process and the power parameters transformations (torque and angle velocity). The paper particularly focuses on the simulation of the main friction clutch during vehicle starting. The process of the simulation model design and the elaborate mathematical models which form its basis are described in detail.

Key words: modeling, friction clutch, simulation.

\section{Uvod}

Tokom poslednjih decenija sve je značajnija upotreba računara u projektovanju sistema motornog vozila, pa tako i elemenata sistema za prenos snage. $U$ današnjoj globalnoj ekonomiji veoma važnu ulogu ima brza isporuka proizvoda na tržište. Vremenski ciklus proizvodnje može biti znatno redukovan korišćenjem kompjuterskih simulacija, pre svega smanjenjem cene proizvoda, utrošenog vremena za izradu prototipa, itd.
Zadovoljenje složenih zahteva koji se postavljaju pred sisteme vozila podrazumeva da se u procesu razvoja mora posmatrati ukupan životni ciklus, uz zadovoljenje principa i metoda sistemskog inženjerstva [1]. U pogledu organizacionog modela i primene savremenih tehnologija razvojni proces mora biti zasnovan na širokoj primeni računarske podrške u svim segmentima razvoja. Računarska podrška razvoju modela mora zadovoljiti, odnosno omogućiti pristup baziran na simultanom projektovanju. To navodi na činjeni- 
cu da je potrebno razviti računarski model proizvoda, koji će zadovoljiti zahteve definisane sistemskim pristupom. Za razvoj sistema za prenos snage potrebno je obezbediti računarsku podršku za dve važne grupe zadataka:

- zadatke koji su vezani za geometrijski model - vizualizacija, provera interference, analiza naponskodeformacionih stanja, simulacija prenosnika snage, itd. i

- zadatke koji se odnose na podršku simulaciji radnih procesa komponenti sistema za prenos snage.

Druga grupa zadataka veoma je značajna i nadograđuje se na prvu, zato što obezbeđuje stvaranje uslova za podršku razvoju sistema za upravljanje prenosnicima snage, kao i mogućnost virtualnih ispitivanja. Za prvu grupu zadataka koriste se razvojni alati koji su zasnovani na savremenim CAD paketima (CATIA, ProEngineer, Ansys, itd.), dok se za simulaciju fizičkih procesa koriste softverski alati bazirani na višim programskim jezicima za rešavanje konkretnih zadataka. Jedan od najviše primenjivanih softvera ovog tipa je MATLAB koji omogućava simulaciju različitih procesa $u$ raznim oblastima.

Imajući tu činjenicu u vidu, u radu je razvijen simulacioni model radnog procesa u glavnoj frikcionoj spojnici motornog vozila, što predstavlja osnovni cilj.

\section{Modeliranje mehaničkih sistema u programskom okruženju MATLAB}

Programski paket MATLAB namenjen je za podršku razvoju u velikom broju oblasti tehnike. Tehnički sistem može se modelirati definisanjem matematičkog modela u okviru programskog jezika MATLAB koji poseduje veliki broj tzv. Toolboxova u kojima su razvijene funkcije koje podržavaju rešavanje zadataka u određenoj oblasti. Drugi način je da se sistem modelira u okviru grafičkog okruženja $\mathrm{Si}$ mulink [2], pomoću kojeg je moguće na lak i jednostavan način definisati simulacioni model. Na taj način omogućava se analiza modela i brza promena njegovih karakteristika i dobijanje odziva. Simulink model praktično se zasniva na grafičkom implementiranju matematičkog modela, tako da se model prevodi u MATLAB program koji se izvršava kao kod definisanja modela programiranjem.

Ovakav način nije pogodan za razvoj modela mehaničkih sistema, tako da je razvijen podmodul SimMechanics koji podržava razvoj mehaničkih sistema preko mehaničkih komponenata. Unutar ovog modula mehaničke komponente se opisuju preko tzv. tela, koja simbolizuju delove mehaničkog sistema i veza između tela. Tela se opisuju koordinatama težišta (centra mase), masom i tenzorom inercije. Veze ograničavaju broj stepeni slobode kretanja tela i na taj način obezbeđuju pravilno funkcionisanje mehaničkog sistema. Pored veza mogu biti definisani i drugi tipovi ograničenja. Veza „mehaničkog“ i klasičnog Simulink okruženja (slika 1) ostvaruje se preko davača (merenje određene veličine) i pobuđivača (zadavanje određene veličine). To znači da se ulaznim veličinama, koje su predstavljene Simulink signalima i predstavljaju određenu matematičku funkciju, preko pobuđivača daje fizički smisao i određuje fizička veličina (ugaona brzina, ubrzanje, moment, sila...). Rezultati si- 
mulacije formiranog mehaničkog modela mere se pomoću davača i kao Simulink signali (određene matematičke funkcije) predstavljaju izlaz iz sistema i mogu biti predstavljeni na odgovarajući način. Grafičko okruženje Simulink, sem omogućavanja definisanja ulaza i izlaza, ima mogućnost definisanja početnih uslova simulacije (IC - Initial conditions).

Dakle, Simulink model predstavlja matematiku kretanja mehaničkog sistema, tj. algebarske i diferencijalne jednačine koje predviđaju buduće stanje mehaničkog sistema na osnovu sadašnjeg stanja. Nasuprot tome, SimMechanics model predstavlja strukturu mehaničkog sistema, geometrijske i kinematske odnose njegovih delova. SimMechanics pretvara ovaj strukturni prikaz u ekvivalentni matematički model.

Prethodno opisano modeliranje mehaničkih sistema vrši se pomoću različitih blokova koji su smešteni u SimMechanics biblioteku (slika 2) i razvrstani su u četiri osnovne grupe: Body, Joint, Constraint, Actuator i Sensor grupe blokova. Kreiranje modela vrši se tako što se željeni blok iz biblioteke blokova jednostavno prenese $u$ novootvoreni model u kojem se dalje vrši odgovarajuće povezivanje blokova. Veze između SimMechanics blokova su pune linije koje predstavljaju fizičke veze i relacije između tela, za razliku od linija u Simulinku koje služe za prenošenje određenih signala. SimMechanics veze ostvaruju se preko različitih portova koji su definisani na blokovima.

Na blokovima Body i ground ti portovi su u obliku kvadratića (slika 2) i pozicija na telu im je tačno definisana lokalnim koordinatnim sistemom.

Druga vrsta portova su tzv. portovi opšte namene koji se pojavljuju na svim ostalim blokovima u obliku kružića (slika 2), koji biva popunjen kada se blokovi povežu. Na Actuator i Sensor blokovima se, pored pomenutih, mogu videti klasični Simulink portovi u obliku strelice preko kojih se ostvaruje ranije objašnjena interakcija između Simulinka i SimMechanicsa (merenje određene veličine i zadavanje određene veličine).

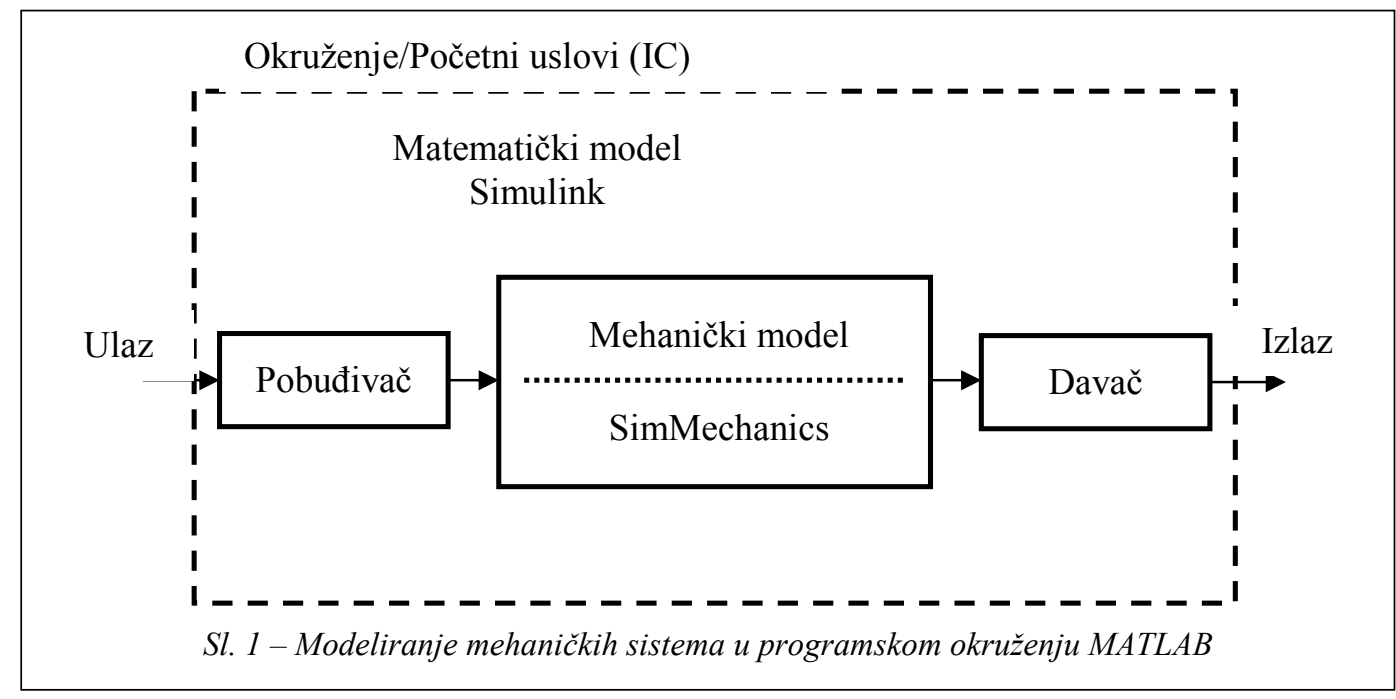




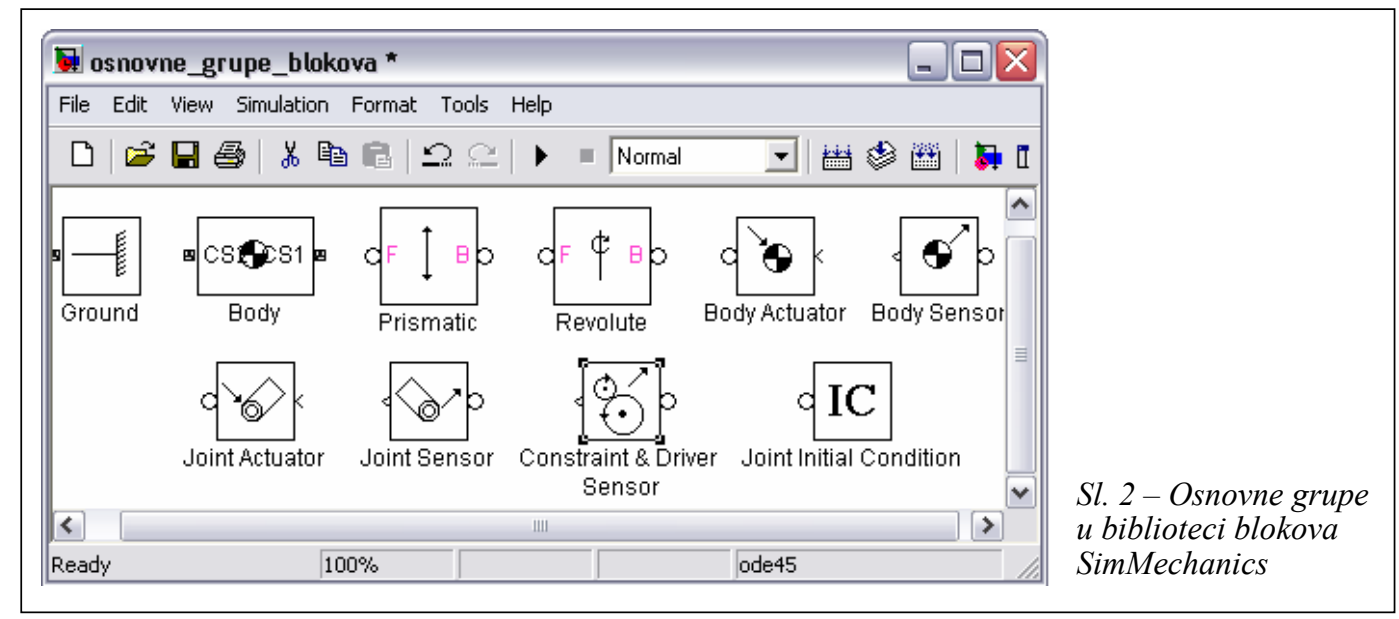

BODY blokovi (tela) predstavljaju mehaničke komponente sistema i imaju određenu masu, momente inercije, kao i definisan položaj u odnosu na izabrani koordinatni sistem. U ovu grupu spada i blok ground koji je telo bez mase i predstavlja fiksirano okruženje ili oslonac. Svaki formirani simulacioni model mora imati bar jedan ovakav blok, jer se onda $\mathrm{u}$ odnosu na njega određuje stepen slobode kretanja koji sistem ima u odnosu na okruženje. Blok ground ima jedan elemenat za vezu (Connector Port), kojim se izabranom vezom povezuje sa drugim elementima modela.
SimMechanics sadrži jedan interni koordinatni sistem i referentnu ravan koji se naziva WORLD koordinatni sistem (slika 3). Koordinate ground bloka mogu biti pomerene u odnosu na referentni, ali im je orijentisanost uvek ista. Sem koordinatnog sistema WORLD, na blokovima koji predstavljaju tela postoji mogućnost određivanja centra mase $(C G)$, kao i položaja drugih tačaka na telu koje predstavljaju lokalne koordinatne sisteme (CS1, CS2,...), koji se mogu definisati u odnosu na:

- referentni koordinatni sistem,

- druge koordinatne sisteme na telu, $\mathrm{i}$

- koordinatni sistem na susednom

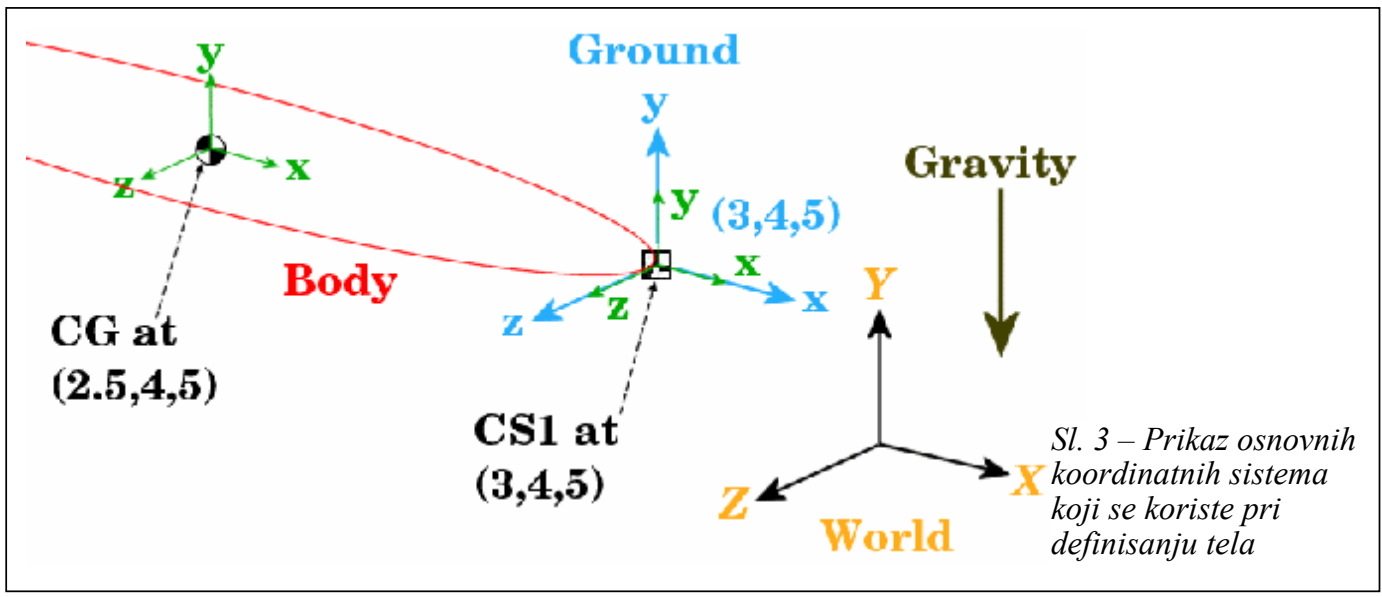


telu (Adjoining $C S$ ) sa kojim je dato telo povezano određenom vrstom veze.

Kao što se vidi sa slike 3, pri formiranju simulacionog modela definiše se i sila gravitacije čiji je pretpostavljeni negativni smer y-ose.

$\mathrm{Na}$ taj način mogu se definisati položaj i dimenzija tela u prostoru, što može da se koristi pri određivanju momenta inercije. Primer na slici 3 prikazuje telo čiji je centar mase u odnosu na tačku oslonca pomeren po x-osi za $0,5 \mathrm{~m}$, čime je praktično definisana $\mathrm{i}$ jedna dimenzija ovog tela.

Na slici 4 vidi se da se pozicija tela definiše tako da se za svaki koordinatni sistem bira da li će biti prikazan sa leve ili desne strane bloka, zatim se definiše njegov vektor položaja $\left[\begin{array}{lll}x & y & z\end{array}\right]$ u izabranim jedinicama mere u odnosu na jedan od ponuđenih koordinatnih sistema (padajući meni desno od menija za izbor jedinice mere). Na ovom padajućem meniju se, pored ostalog, pojavljuje i opcija za izbor prethodno pomenutog Adjoining $C S$. Sem toga, SimMechanics obezbeđuje i mogućnost određivanja orijentisanosti tela u prostoru (slika 4). Izgled prozo- ra za orijentaciju vrlo je sličan prethodnom, s tim što se bira određena uglovna pomerenost $\mathrm{u}$ odnosu na referentni koordinatni sistem.

Dodavanje, brisanje i uopšte ažuriranje podataka u ovom prozoru izvršava se jednom od komandi koje se nalaze $u$ gornjem desnom uglu.

Sem definisanja pozicije i orijentacije tela, preko sličnog prozora definišu se masa i momenti inercije tela. Moment inercije definiše se preko sledeće trodimenzionalne dijagonalne matrice

$$
\left[\begin{array}{ccc}
I_{1} & 0 & 0 \\
0 & I_{2} & 0 \\
0 & 0 & I_{3}
\end{array}\right]
$$

gde su $I_{1}, I_{2}, I_{3}$ momenti inercije tela oko $\mathrm{x}, \mathrm{y}, \mathrm{z}$ ose.

JOINT blokovi (veze) predstavljaju stepene slobode kretanja koje jedno telo (prateće) ima u odnosu na drugo (bazno) (slika 5).

SimMechanics veze pridružuju stepene slobode kretanja modelu, pošto su blokovi koji predstavljaju tela definisani

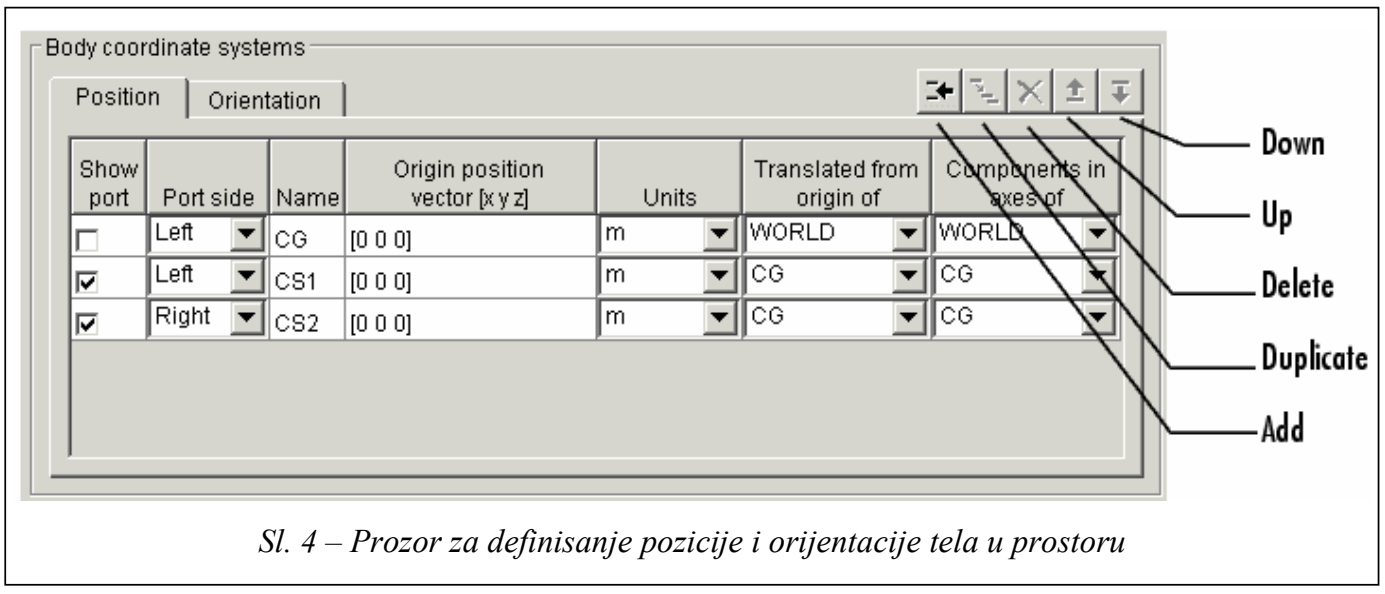


tako da ne poseduju nijedan stepen slobode kretanja. Bazno telo u vezi može biti i oslonac (ground). SimMechanics veza ne implicira obavezno i fizičku vezu između dva tela, za šta je osnovni primer takozvana Six-Dof veza kojom se može simulirati kretanje aviona kao pratećeg tela u odnosu na Zemlju kao bazno telo. Osnovne vrste veza koje su dostupne u SimMechanics biblioteci blokova su:

- prizmatična (prismatic $-P$ ), koja obezbeđuje jedan stepen slobode kretanja duž prave;

- rotaciona (revolute $-R$ ), koja obezbeđuje jedan stepen slobode kretanja oko ose rotacije (slika 5);

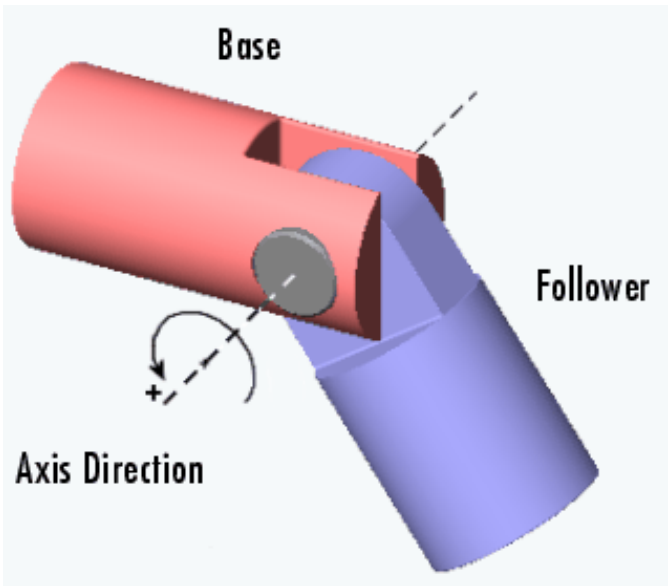

Sl. 5 - Rotaciona veza između dva tela - bazno $i$ prateće

- sferna (spherical - S), koja obezbeđuje tri stepena slobode kretanja oko tačke (pivot), i

- čvrsta (weld - $W$ ), koja ima nula stepeni slobode kretanja.

Njihovom kombinacijom može se dobiti više vrsta složenih veza koje predstavljaju idealizovane realne veze (npr. Bearing koja predstavlja ležaj). Bitno je naglasiti da svaka vrsta veze može da povezuje samo dva tela, ne više njih.

CONSTRAINT blokovi definišu (ograničavaju) način međusobnog relativnog kretanja tela. Postoji, na primer, ovakav blok koji određuje da se dva tela kreću po paralelnim putanjama (slika 6) na definisanom odstojanju.

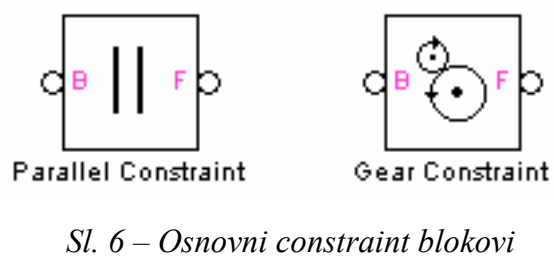

Najpoznatiji constraint blok je gear (slika 6), koji ograničava kretanje dva tela na način da je ono istovetno kretanju spregnutog zupčastog para. Njegova upotreba i način definisanja parametara imaju konkretnu primenu kod modeliranja procesa rada menjačkog, glavnog i diferencijalnog prenosnika. Ovi blokovi služe da smanje, tj. ograniče određeni broj, prethodno pomoću odgovarajuće veze definisanih stepeni slobode kretanja. Osnovna ograničenja koja se moraju ispoštovati pri korišćenju constraint blokova su da:

- mogu da se pojave samo u zatvorenim konturama;

- svaka zatvorena kontura može da sadrži samo jedan blok ove vrste, $i$

- mogu da povezuju samo dva tela međusobno.

ACTUATOR blokovi (pobuđivači) omogućavaju nekoliko bitnih stvari:

- uvođenje vremenski zavisnih sila i momenata na tela i veze;

- uvođenje brzine i ubrzanja kao funkcije vremena na veze, kao i 
- određivanje početne pozicije i početne brzine veze u modelu.

Potrebno je naglasiti da se na telo ne može aplicirati bilo kakvo kretanje, pošto je ranije naglašeno da tela nemaju nijedan stepen slobode kretanja, kao i da se pobuđivač ne može vezati na čvrstu i sfernu vezu.

Pored odabira referentnog koordinatnog sistema, pri pobuđivanju tela data je mogućnost apliciranja sile (slika 7) ili obrtnog momenta. Kao ulaz u pobuđivač može se iskoristiti bilo koji Simulink signal u obliku funkcije ili matrice, kao i izlazni signal iz bilo kog davača, čime se praktično omogućava formiranje povratne veze.

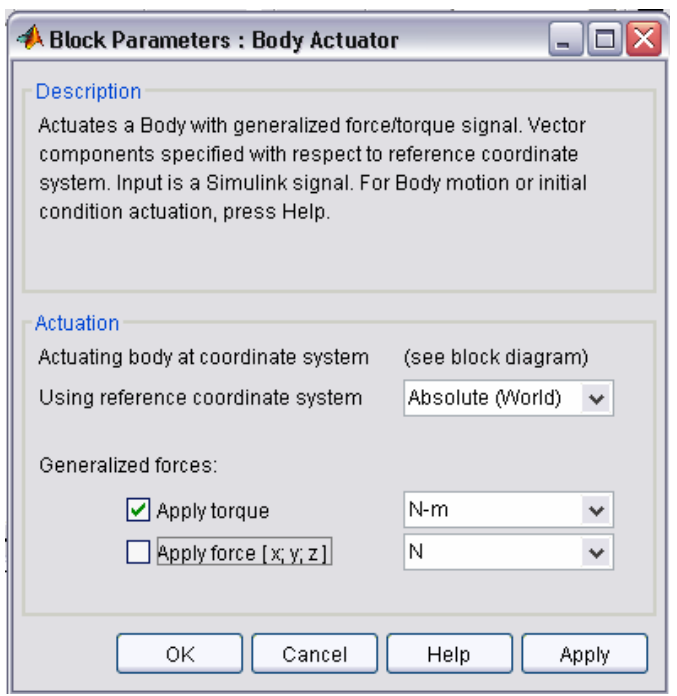

Sl. 7 - Prozor za definisanje osnovnih parametara aktuatora tela

Pobuđivanje veze vrši se pomoću pobuđivača kojim se na vezu može aplicirati:

- sila ili translatorno kretanje (ali ne oboje) na prizmatične veze,

- moment ili rotaciono kretanje (ali ne oboje) na rotacione veze.
Specifična vrsta pobuđivača veze je Joint Initial Condition Actuator (IC), koji predstavlja blok za definisanje početne brzine i početne pozicije veze. Pretpostavljena početna brzina na vezi je jednaka nuli. Ako se želi da ona u početnom trenutku simulacije modela ima neku vrednost koristi se IC blok, koji se u model prenosi iz biblioteke blokova, povezuje preko aktuator porta za vezu i onda se preko prozora na slici 8 unose njegovi parametri (informacija za koju je vezu povezan, početna pozicija i početna brzina u odgovarajućim jedinicama). IC je pobuđivač koji za razliku od svih ostalih pobuđuje vezu samo u početnom trenutku simulacije i ne deluje na vezu dalje u toku simulacije modela. Ovaj blok, za razliku od ostalih blokova pobuđivača, nema ulazni port u sebe i ne zahteva Simulink signal kao ostali, zato što sam po sebi predstavlja ulaz u sistem. Ni ovaj blok se ne može koristiti za pobuđivanje sferične i čvrste veze.

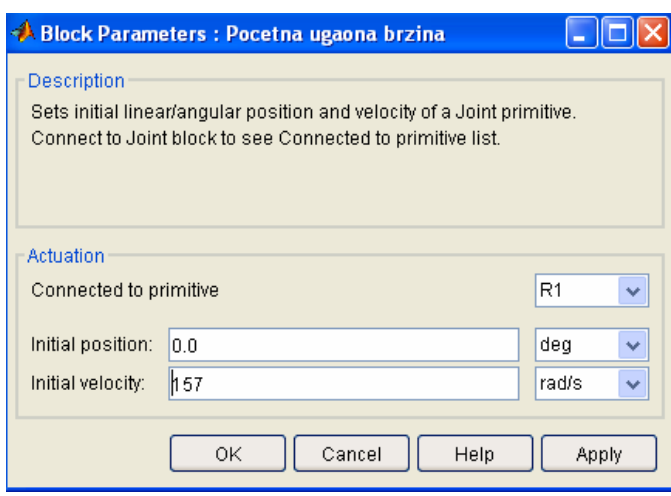

Sl. 8 - Prozor za definisanje osnovnih parametara IC aktuatora veze

SENSOR (davač) blokovi predstavljaju davače za merenje sledećih veličina:

- pozicije, brzine i ubrzanja tela pri kretanju (slika 9), 
- sile, momenata i kinematskih karakteristika na vezama,

- sile i momenata reakcije na constraint blokovima.

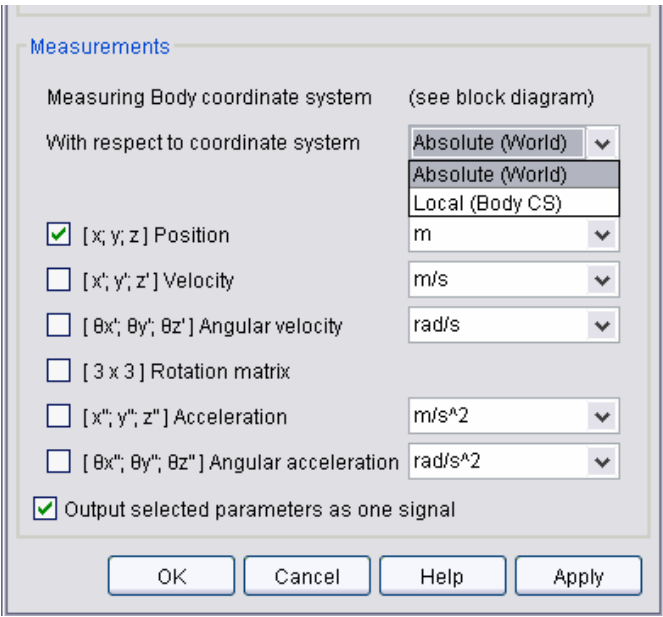

Sl. 9 - Prozor za definisanje osnovnih parametara davača koji se veže za telo

Po pitanju merenja kinematskih veličina tela koja se nalaze $u$ vezi sa nekim drugim telom, sa slike 9, vidi se da je moguće meriti brzine i ubrzanja pri translatornom i rotacionom kretanju, uz izbor željenih mernih jedinica. U padajućem meniju, koji je prikazan na ovoj slici, prikazana je mogućnost izbora referentnog koordinatnog sistema u odnosu na koji se vrši merenje. Sem merenja kinematskih veličina na telima, one se mogu, putem davača, meriti i na vezama između tela. U zavisnosti od vrste veze koja se koristi mere se, kod prizmatičnih veza, pozicija, brzina i ubrzanje, a kod rotacionih veza ugaona brzina i ubrzanje. Blok davača omogućava merenje relativne sile i momenta između tela u vezi (computed force, computed torque), a to su sile i momenti koji omogućavaju kretanje tela. Sem toga, pomoću ovog bloka moguće je meriti i sile i momente reakcije na vezama. U slučaju da se blok davač poveže na constraint blokove, postoji mogućnost merenja jedino sila i momenata reakcije.

Modul SimMechanics, pored ostalog, omogućava da se veza dva rotaciona elementa modelira na taj način da se uključe karakteristike trenja unutar veze pomoću bloka pobuđivača koji se naziva JOINT STICTION ACTUATOR (slika 10) i koji predstavlja specijalno razvijen oblik pobuđivača.

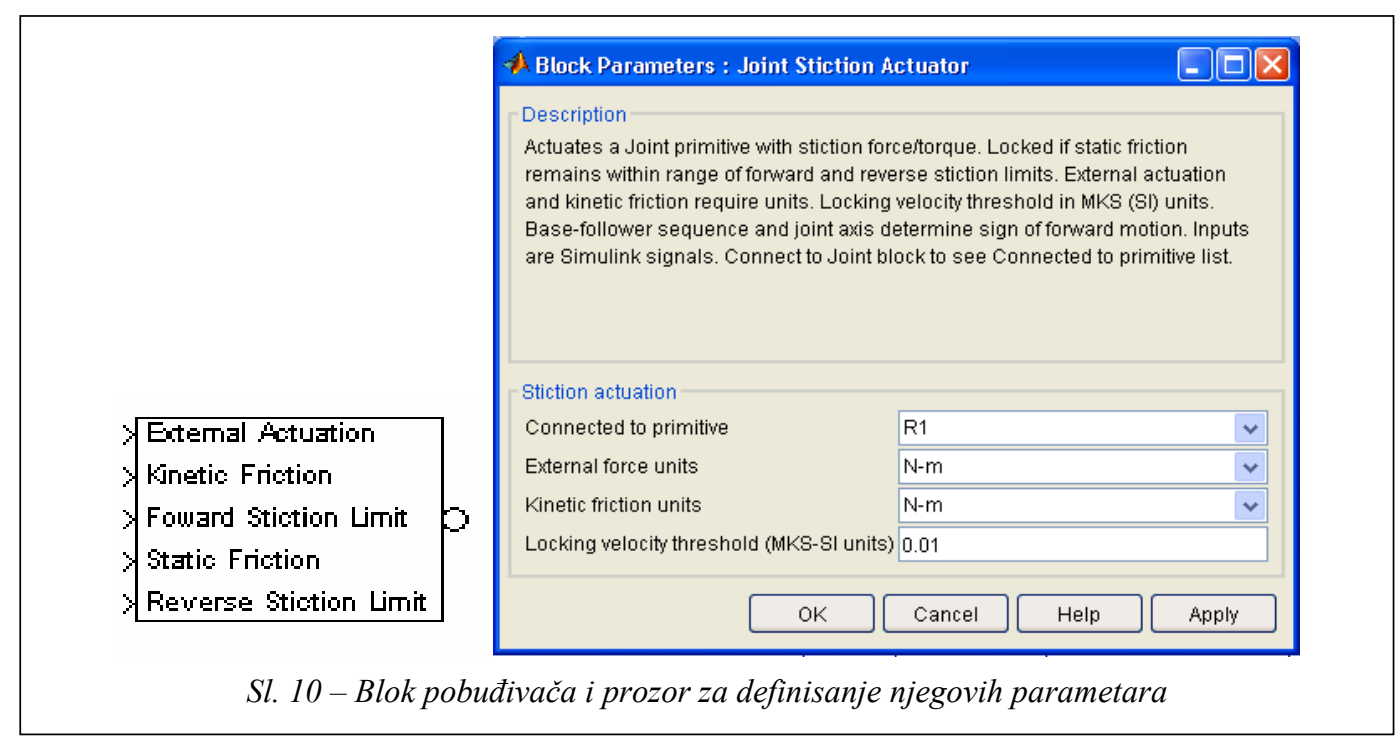


Ovaj blok omogućava da se u vezi pojavi sila trenja (translatorni sistem) ili moment trenja (rotacioni sistem). Moment trenja kod rotacionog sistema izračunava se u funkciji sledećih veličina:

- spoljašnji moment $\left(\mathrm{M}_{\text {ext }}\right)$ - model omogućava uvođenje spoljašnjeg momenta koji deluje na vezu i nezavisan je od momenta trenja,

- trenje kotrljanja/klizanja $\left(\mathrm{M}_{\mathrm{k}}\right)$ predstavlja moment trenja koji deluje na elemente $\mathrm{u}$ rotaciji dok traje proces proklizavanja,

- granica statičkog momenta trenja $\left(\mathrm{M}_{\mathrm{s}}\right)$ - omogućava određivanje opsega momenta trenja u kome dolazi do ,zaključavanja veze" i to stanje traje dok god moment na vezi dva tela ne izađe iz ovog opsega,

- prag brzine „,zaključavanja“ ( $\omega z)$
- predstavlja relativnu ugaonu brzinu tela u rotaciji ispod koje prestaje proklizavanje, što dovodi do ostvarivanja čvrste veze tela i njihovog zajedničkog kretanja.

Pored kontinuiranog kretanja, veza ostvarena preko modela trenja može da se nalazi u još nekoliko diskretnih stanja: zaključanom, otključanom i prelaznom (slika 11). Pobuđivač vrši prebacivanje iz jednog u drugo stanje putem detekcije veličina koje unosimo kao ulazne parametre. Dva osnovna uslova koja određuju trenutak prelaska iz jednog u drugo stanje definišu se preko četiri ulazna parametra:

- prag brzine ,zaključavanja“ $\left(\omega_{z}\right)$,

- donja granica statičkog momenta trenja $\left(\mathrm{M}_{\mathrm{sd}}\right)$,

- gornja granica statičkog momenta trenja $\left(\mathrm{M}_{\mathrm{sg}}\right)$,

- moment na vezi $\left(M_{n}\right)$.

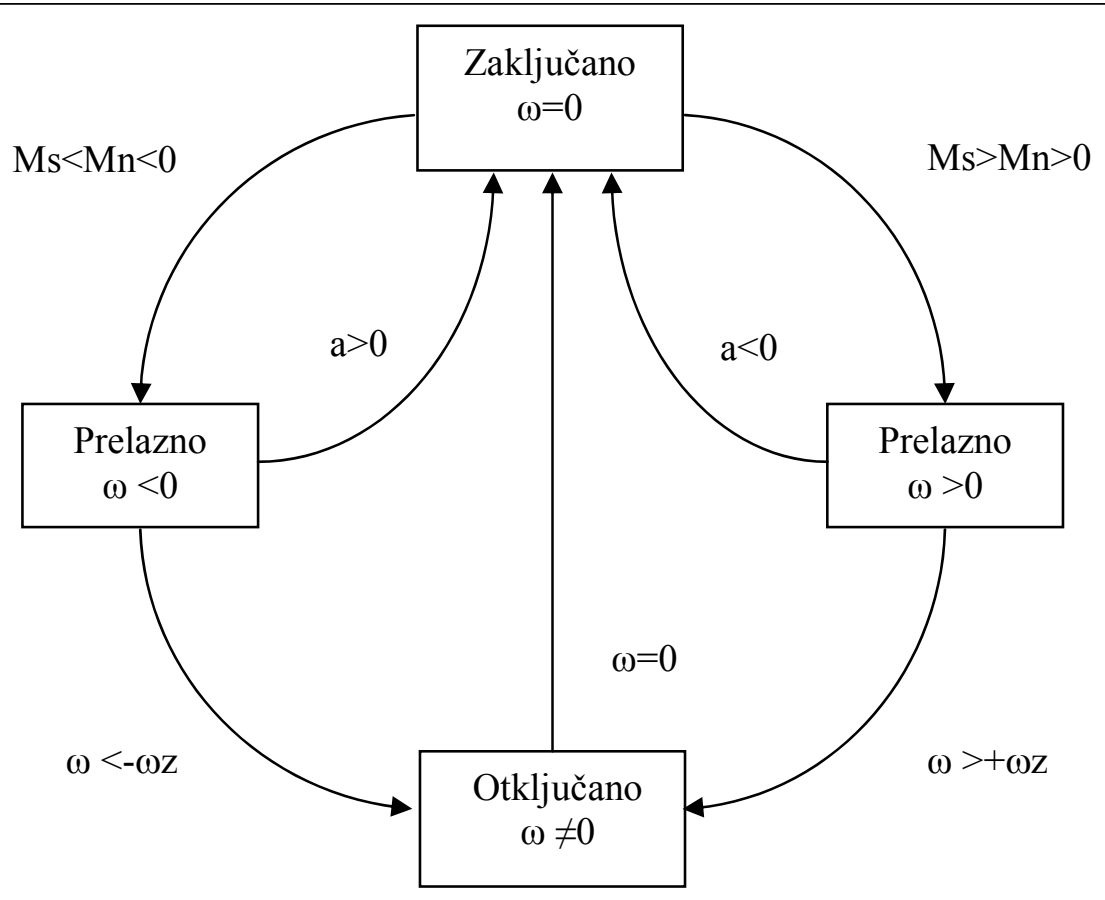

Sl. 11 - Diskretna stanja elemenata u vezi koja simulira trenje 
U zaključanom stanju relativna ugaona brzina elemenata u vezi jednaka je nuli $(\omega=0)$. Ovakvo stanje traje dokle god je moment trenja na vezi u granici između donje i gornje granice statičkog trenja $\mathrm{M}_{\mathrm{sd}}<\mathrm{M}_{\mathrm{n}}<\mathrm{M}_{\mathrm{sg}}$.

$\mathrm{U}$ trenutku kada moment trenja na vezi $M_{n}$ izađe iz granica statičkog momenta trenja na vezi ispunjen je prvi uslov za otključavanje, simulacija ulazi u prelazno stanje i počinje kretanje u jednom $(\omega>0)$ ili drugom smeru $(\omega<0)$. Međutim, ako ugaona brzina u prelaznom stanju nije velika, tj. ako nema ugaonog ubrzanja veza se vraća u zaključano stanje. U slučaju kada postoji porast ugaone brzine, dešava se da ona preraste prag brzine $\omega_{z} \mathrm{i}$ tada je ispunjen drugi uslov za otključavanje veze.

U otključanom stanju kretanje tela u vezi ostvaruje se uz proklizavanje pod dejstvom spoljašnjeg momenta $\left(\mathrm{M}_{\mathrm{ext}}\right) \mathrm{i}$ kinetičkog momenta trenja $\left(\mathrm{M}_{\mathrm{k}}\right)$. Prelazak iz otključanog u zaključano stanje na vezi dešava se kada SIMULINK detektuje da je ugaona brzina dostigla vrednost nula.

Prethodno opisani blok Joint Stiction actuator iskorišćen je za modeliranje procesa uključivanja glavne frikcione spojnice motornog vozila.

\section{Prikaz simulacionog modela glavne frikcione spojnice motornog vozila}

Mehaničke frikcione spojnice su elementi sistema za prenos snage koji imaju karakteristična radna opterećenja u procesu uključivanja (polaska motornog vozila iz mesta), tako da je upravo taj proces najbitniji za projektovanje, pa i za kompjutersku simulaciju rada spojnice.

Da bi se razvio simulacioni model potrebno je prethodno razviti matematički model uključivanja spojnice, koji je za potrebe ovog rada razvijen tako da predstavlja dve rotacione mase (pogonsku i gonjenu), na koje deluje normalna sila koja ih približava. Pogonskoj masi zadata je početna ugaona brzina. Pod dejstvom normalne sile, usled trenja na površinama ove dve mase, dolazi do izjednačavanja njihovih ugaonih brzina. Simulacioni model (slika 12) koncipiran je tako da predstavlja simulaciju uključivanja spojnice kao kada se to obavlja pri ispitivanju na probnom stolu PSS-30 [3] na Mašinskom fakultetu u Beogradu.

Motor radi pri zadatoj ugaonoj brzini, u željenom trenutku se uključuje spojnica, pri čemu dolazi do smanjenja ugaone brzine motora i povećanja ugaone brzine spojnice (njenih gonjenih delova). U toku procesa uključivanja ove dve brzine teže izjednačavanju, koje se postiže na kraju uključivanja spojnice. Tokom ovog procesa prati se i promena momenta nošenja spojnice u toku vremena klizanja.

Veoma je bitno naglasiti da ovaj model razmatra isključivo polazak motornog vozila s mesta, što podrazumeva da je u početnom trenutku simulacije $u$ menjačkom prenosniku izabran prvi stepen prenosa, i da se takvo stanje posmatra kroz simulaciju ostalih elemenata sistema za prenos snage (menjača, glavnog i diferencijalnog prenosnika).

Ostali granični uslovi potrebni za ovu simulaciju rada mogu se definisati u MATLAB-u na dva različita načina: eksperimentalnim rezultatima ili matematičkim modelima. 


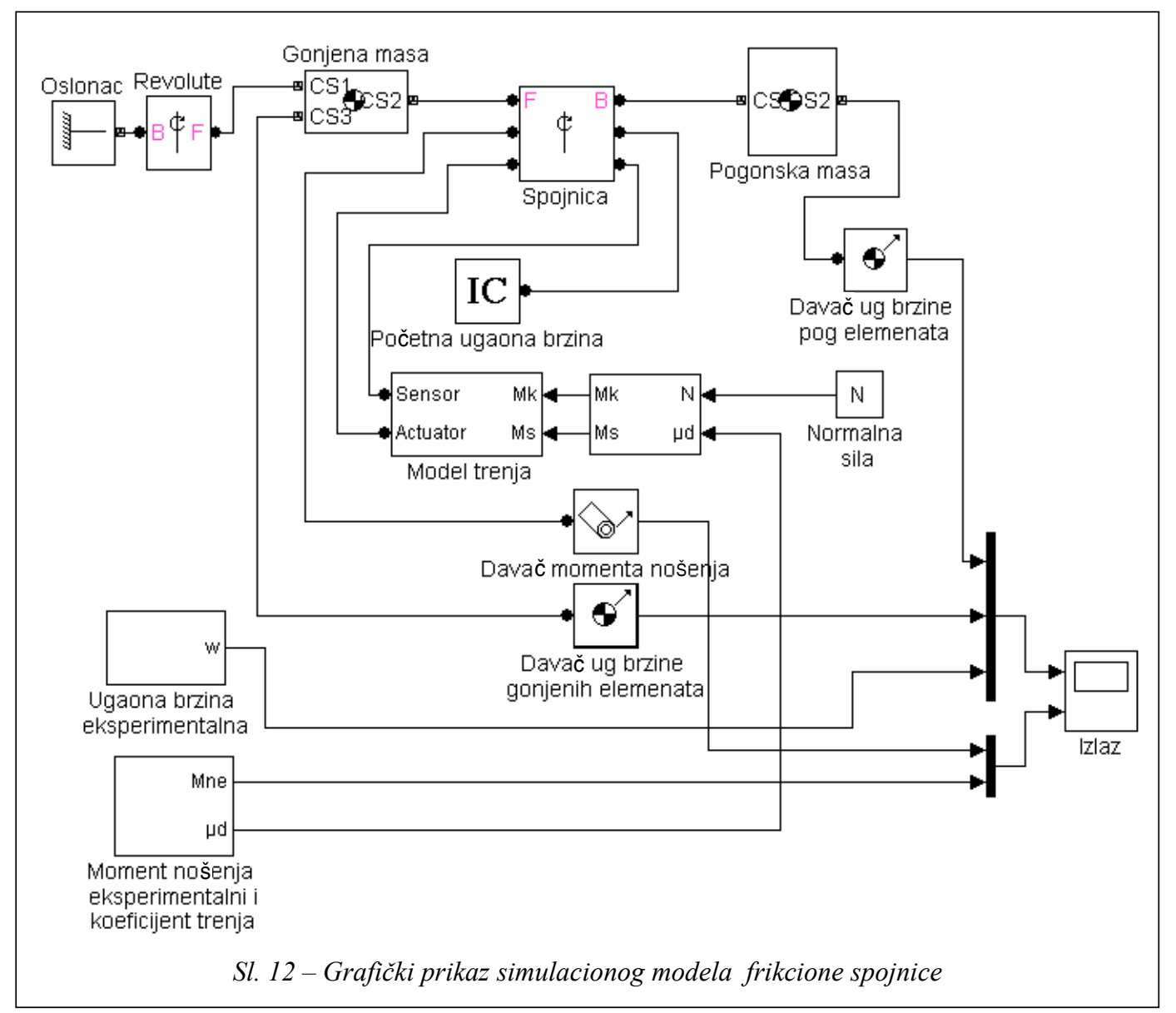

Prvi način definisanja graničnih uslova simulacije rada prenosnika snage pri polasku motornog vozila iz mesta podrazumeva korišćenje eksperimentalnih rezultata dobijenih pri ispitivanju procesa uključivanja spojnice jednog putničkog vozila na probnom stolu. Eksperimentalni rezultati sa probnog stola, koji su pohranjeni u Microsoft Excelu, pomoću MATLAB programa se prevode $\mathrm{u}$ jednodimenzionalne matrice (arrays) koje se smeštaju u radni prostor MATLAB-a i mogu da se koriste. U razvijenom simulacionom modelu moment nošenja spojnice, dobijen eksperimentalnim putem, iskorišćen je za izračunavanje zakona promene koeficijenta trenja na frikcionim površinama $u$ toku vremena uključivanja. Koeficijent trenja, zajedno sa normalnom silom, predstavlja osnovne ulazne veličine za simulacioni model trenja prikazan na slici 12 .

Formirani model i korišćena procedura simulacije omogućavaju dobijanje relevantnih parametara procesa uključivanja spojnice za različite ulazne parametre. Segment prezentovanih eksperimentalnih rezultata u ovom radu odnosi se na ispitivanje na probnom stolu spojnice namenjene za putničko vozilo sa sledećim pola- 


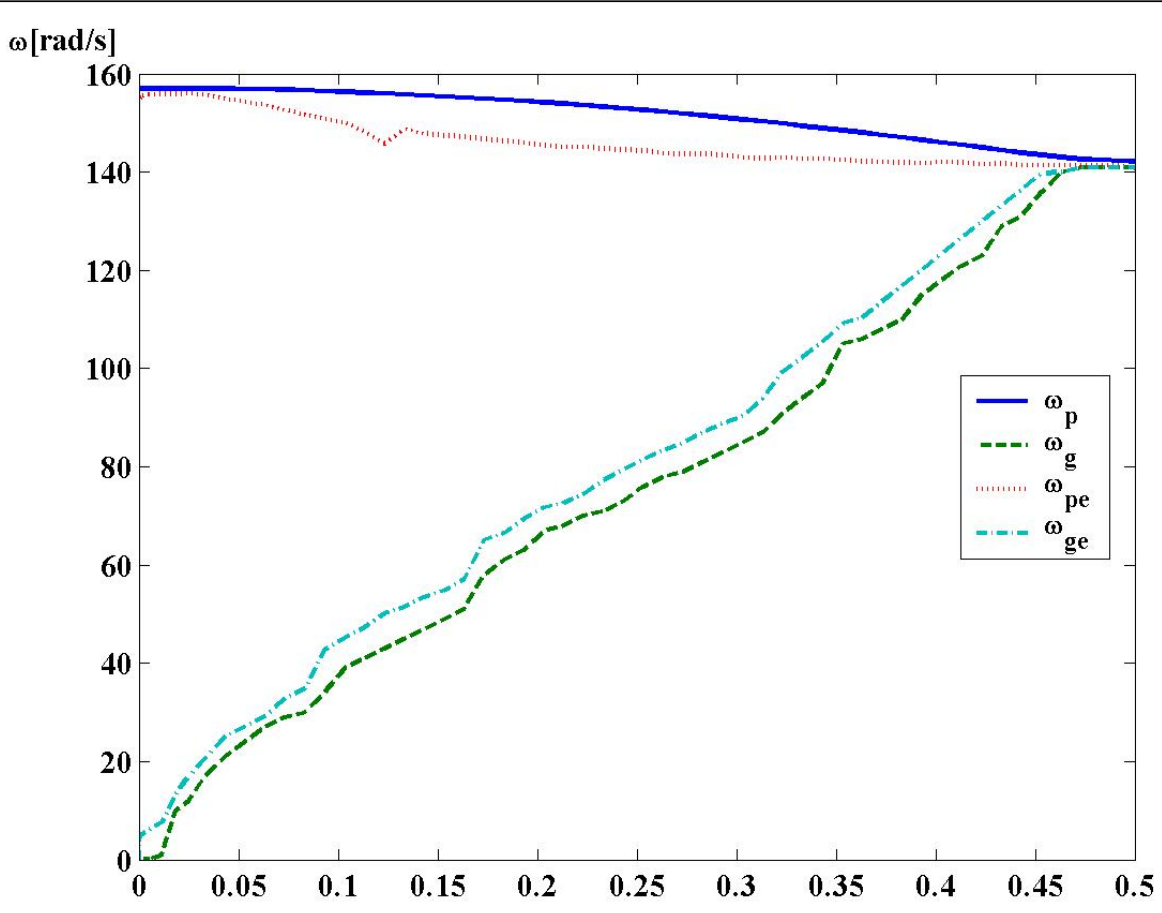

Sl. 13 - Uporedni dijagram promena ugaonih brzina eksperimenta i simulacije

znim podacima: ukupna masa $970 \mathrm{~kg}$, poluprečnik frikcione površine $0,09 \mathrm{~m}$ i $0,0635 \mathrm{~m}$, jednolamelasta spojnica sa zavojnim oprugama. Normalna sila pritiska na potisnoj ploči definisana je linearnom rastućom zavisnošću u funkciji vremena sa maksimalnom vrednošću od $2590 \mathrm{~N}$. Koeficijent trenja na frikcionim površinama je promenljiv u vremenu sa maksimalnom vrednošću 0,375 .

Slika 13 ilustruje promenu ugaonih brzina pogonskih i gonjenih elemenata, a slika 14 momenta nošenja spojnice $u$ toku vremena uključivanja. Pri izvođenju simulacije na formiranom modelu korišćeni su realni eksperimentalni podaci za normalnu silu i za izračunavanje realne promene koeficijenta trenja, kao i realni podaci o poluprečnicima frikcionih povr- šina spojnice koja je ispitivana na probnom stolu. Na ovako formiranom modelu izveden je veliki broj simulacija, pri kojima se ispostavilo da najviše uticaja na vreme klizanja imaju momenti inercije pogonskih i gonjenih elemenata spojnice. Prikazani dijagrami dobijeni su za određene vrednosti momenata inercije i predstavljaju reprezentativan primer svih izvedenih simulacija.

Sa dijagrama na slici 13 vidi se da postoji saglasnost, kako u veličini, tako i u karakteru promene ugaonih brzina pogonskih (opada) i gonjenih elemenata spojnice (ugaona brzina raste). Razlika se ogleda $u$ tome što eksperimentalne ugaone brzine imaju određene oscilacije, dok su one dobijene simulacijom ,ispeglane". 


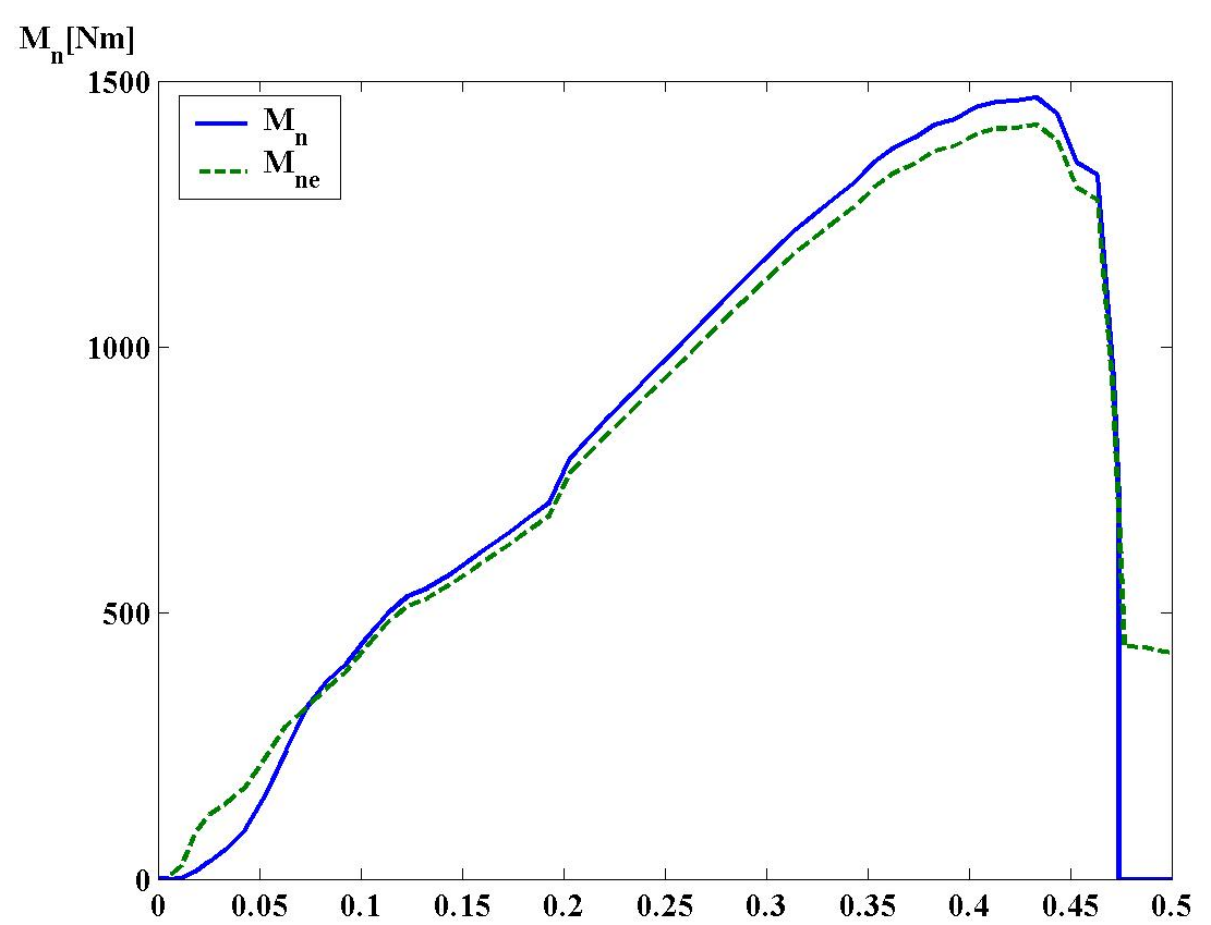

$\mathrm{t}[\mathbf{s}]$

Sl. 14 - Uporedni dijagram promena momenta nošenja eksperimenta i simulacije

Što se tiče momenta nošenja, razlika između simulacionih i eksperimentalnih rezultata je neznatna i najuočljivija po prestanku proklizavanja, jer tada moment nošenja dobijen simulacijom pada na nulu. Naime, u simulacionom modelu ne postoji moment opterećenja spojnice i ugaona brzina nakon uključivanja ostaje konstantna.

\section{Zaključak}

Savremenim pristupom razvoju koji je podržan računarom smanjuje se mogućnost unošenja greške pri razmeni rezultata simulacije između različitih programa koji su ranije omogućavali samo jedan vid analize [4]. Takođe, potrebno je i moguće da budu izbegnute aproksi- macije, pretpostavke i uprošćenja koja nastaju kao posledica međusobnog usklađivanja pojedinih programa, pa se na taj način stvaraju pretpostavke za još bolje približavanje uslovima za simulaciju primenjenu na trodimenzionalne virtuelne modele u vezi sa realnim uslovima rada posmatranog mašinskog sklopa. Tako se dodatno utiče na dalje ubrzanje i optimizaciju samog procesa projektovanja i proizvodnje, čime se stvaraju dodatni uslovi za razvoj efikasnijih, kreativnijih, pouzdanijih i jeftinijih proizvoda, odnosno, čime se smanjuju ukupni troškovi i vreme potrebno za stvaranje i plasman novog proizvoda na tržište.

Jedan od važnih preduslova za redukovanje vremenskog ciklusa proizvodnje 
i troškova razvoja mašinskog sistema svakako je sistemska primena računarskih modela, pomoću kojih se obezbeđuje zadovoljenje postavljenih zahteva. $\mathrm{S}$ obzirom na značaj glavnih frikcionih spojnica, adekvatni modeli za proučavanje njihovih radnih procesa i savremene metode simulacije jesu dobra polazna osnova za njihovo projektovanje. Razvijeni model spojnice zadovoljava postavljene zahteve i omogućuje adekvatnu simulaciju ispitivanja performansi spojnica za različite ulazne parametre, a pre njihovog postavljanja na probni sto. Model se može iskoristiti i za modeliranje frikcionih elemenata unutar automatizovanih menjačkih prenosnika radi istraživanja prelaznih procesa pri promeni stepena prenosa.

Literatura:

[1] Duboka, Č., Arsenić, Ž.: Sistemsko inženjerstvo u razvoju, proizvodnji i korišćenju mašinskih sistema, 25. savetovanje proizvodnog mašinstva Jugoslavije, Beograd, 1994.

[2] MATLAB Using Simulink and Stateflow ${ }^{\mathrm{TM}}$ in Automotive Aplication, 1999.

[3] Duboka, Č., Arsenić Ž.: Ispitivanje motornih vozila, priručnik, JUMV, Beograd, 1994.

[4] Muždeka, S.: Primena metoda sistemskog inženjerstva u razvoju planetarnih prenosnika, magistarski rad, Mašinski fakultet, Beograd, 2002. 
Okruženje/Početni uslovi (IC)

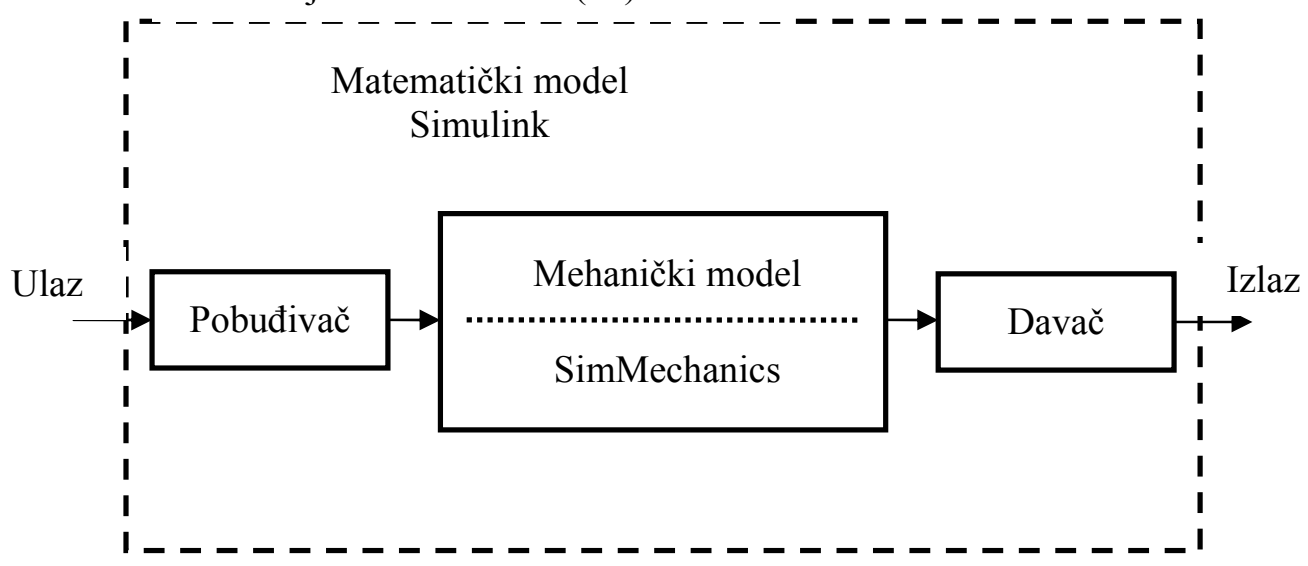

Sl. 1 - Modeliranje mehaničkih sistema u programskom okruženju MATLAB

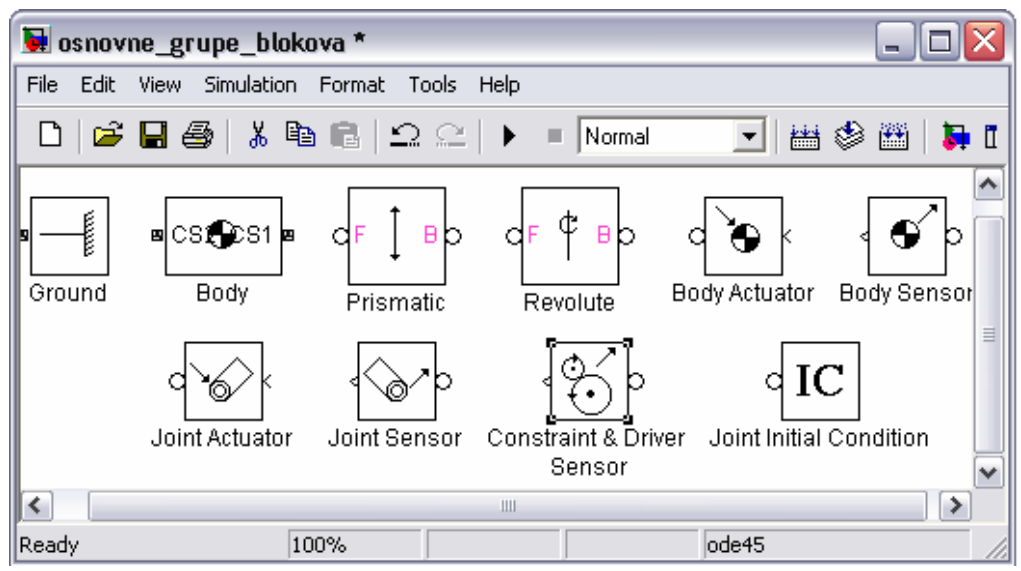

Sl. 2 - Osnovne grupe u biblioteci blokova SimMechanics

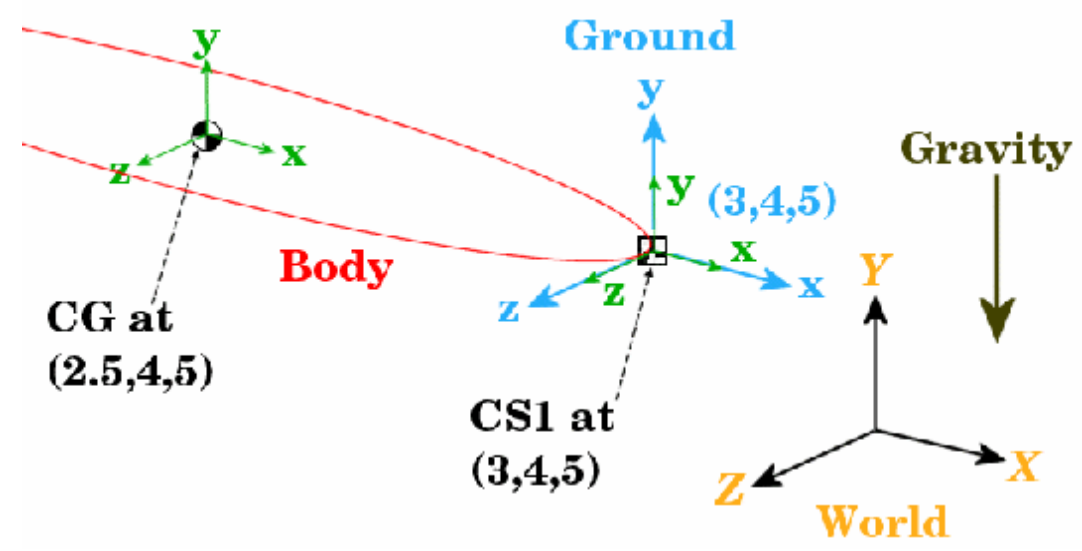

Sl. 3 - Prikaz osnovnih koordinatnih sistema koji se koriste pri definisanju tela 


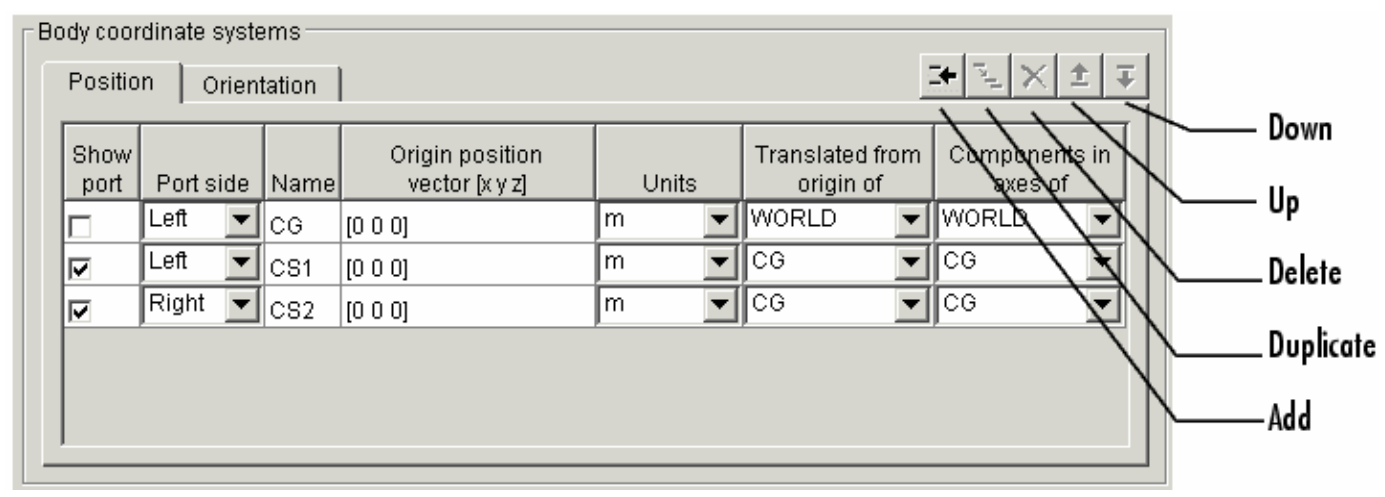

Sl. 4 - Prozor za definisanje pozicije i orijentacije tela u prostoru

Extemal Attuation
Fnetic Friction
Fowand Stiotion Limit
Static Friction
Feverse Stiction Limit

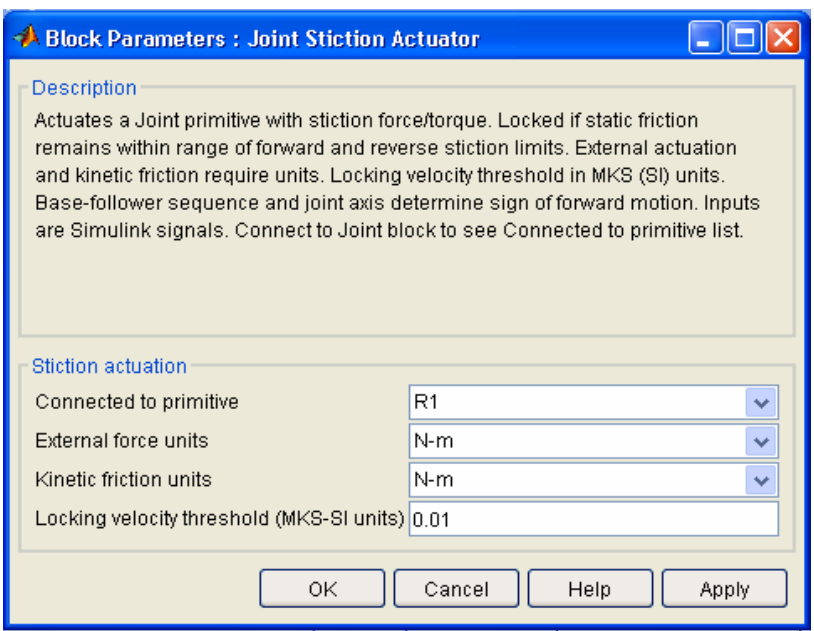

Sl. 10 - Blok pobuđivača i prozor za definisanje njegovih parametara

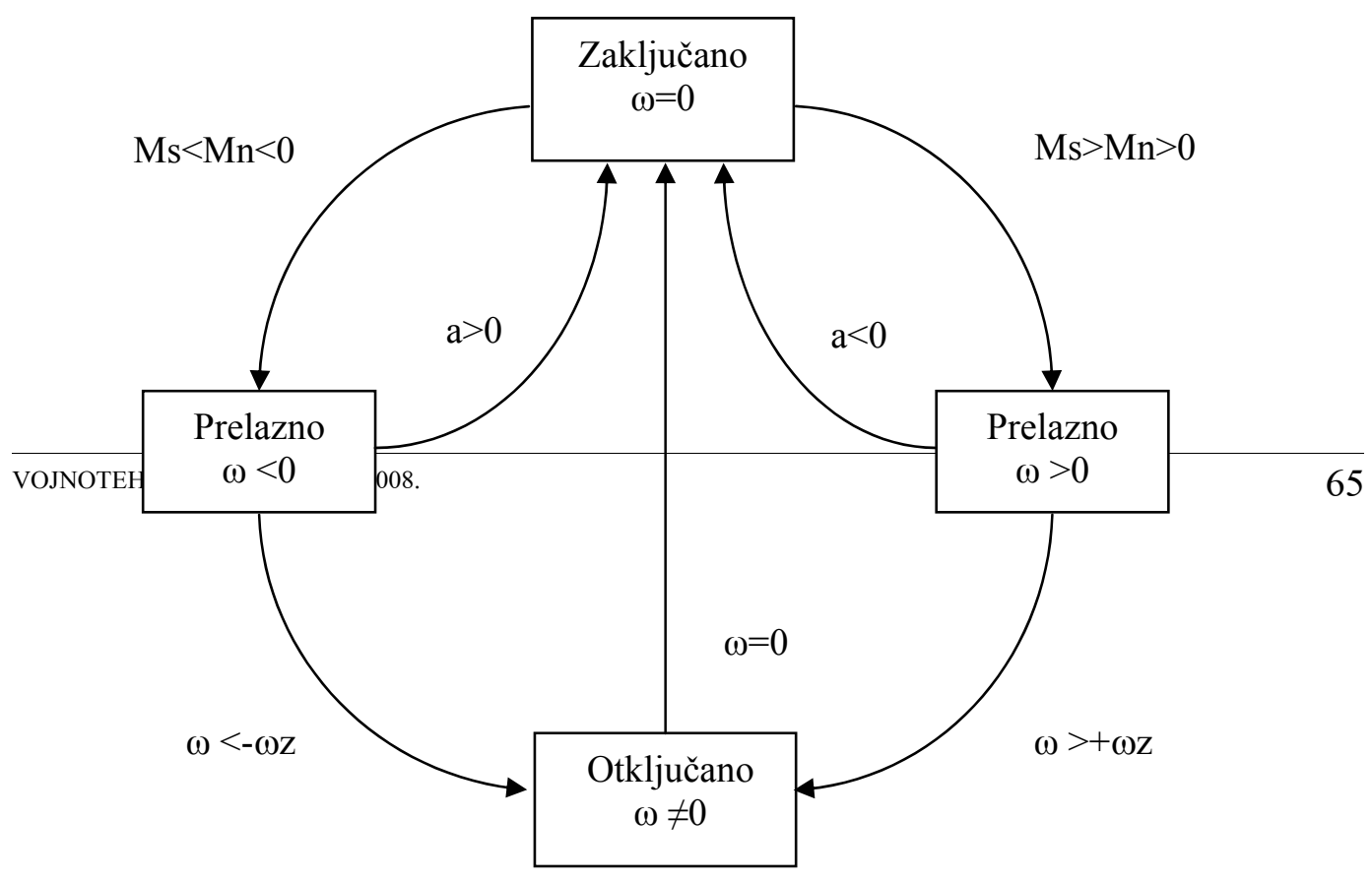




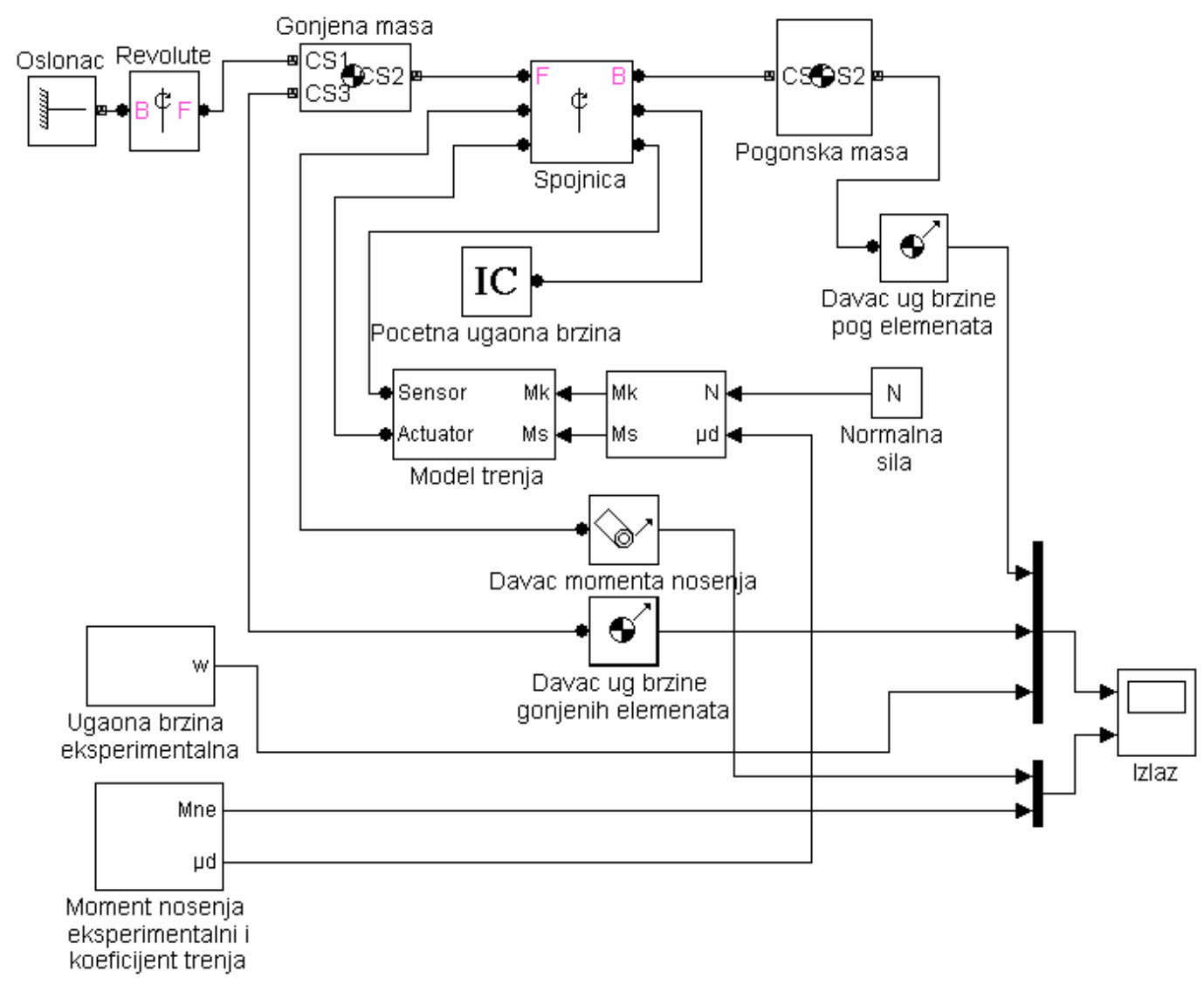


Sl. 12 - Grafički prikaz simulacionog modela frikcione spojnice

$\omega[\mathrm{rad} / \mathrm{s}]$

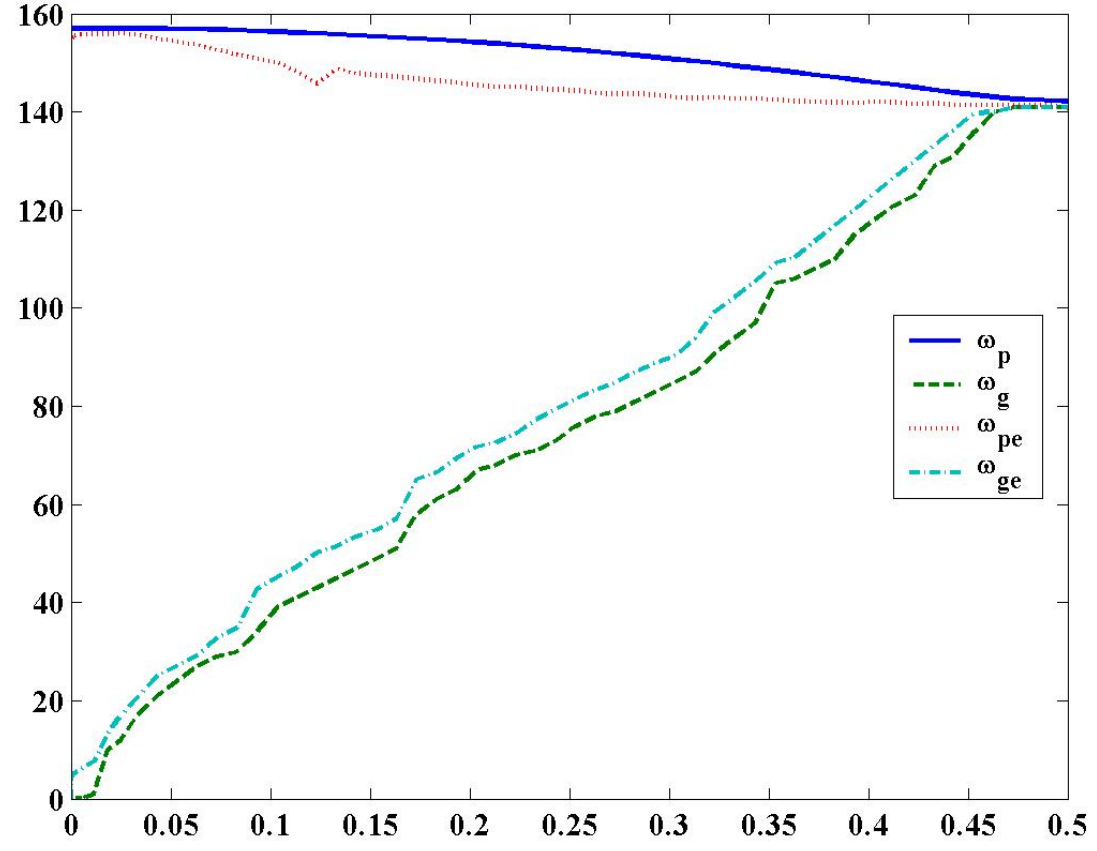

Sl. 13 - Uporedni dijagram promena ugaonih brzina eksperimenta i simulacije 


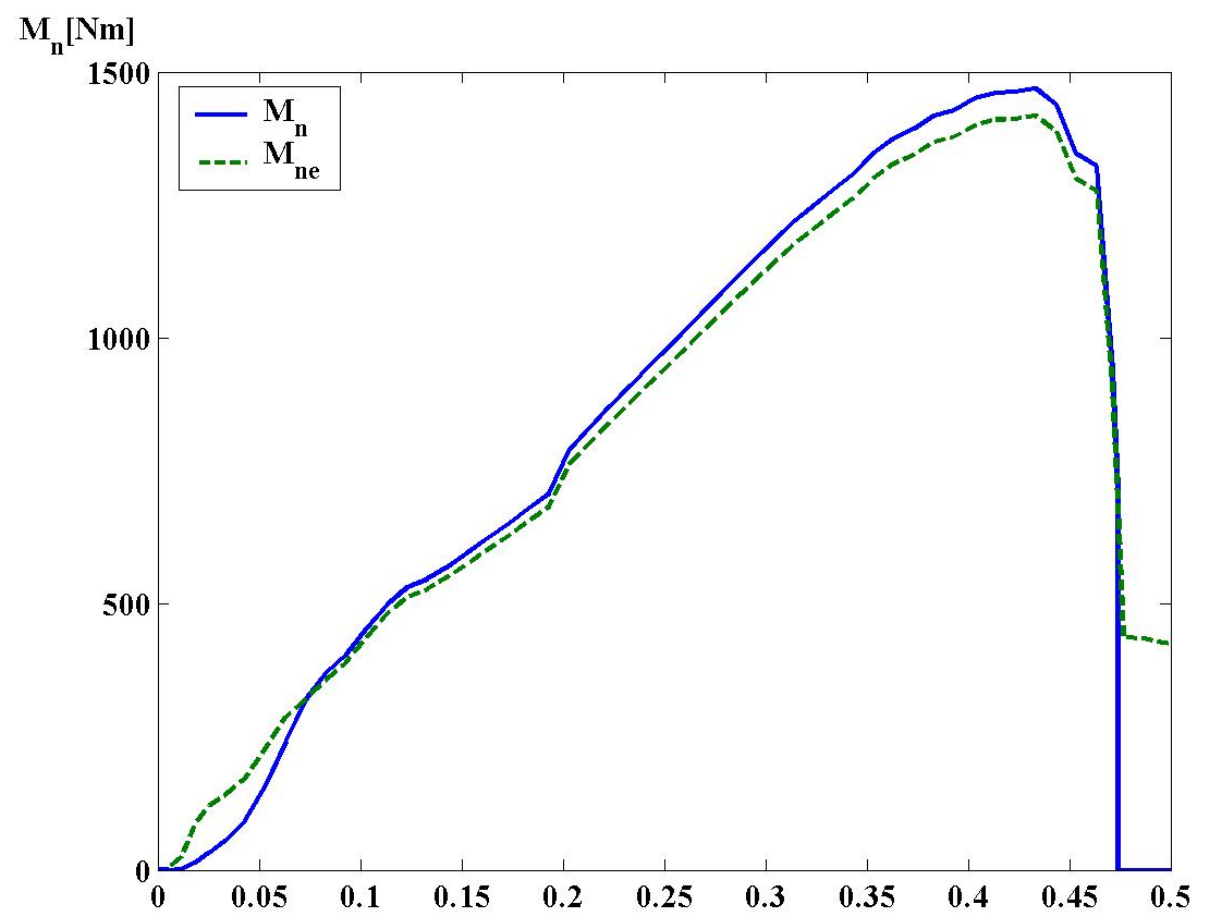

$\mathrm{t}[\mathrm{s}]$

Sl. 14 - Uporedni dijagram promena momenta nošenja eksperimenta i simulacije 